\title{
Correction to: Enzymatic studies on aromatic prenyltransferases
}

\author{
Takahiro Mori $^{1}$
}

Published online: 28 May 2020

(c) The Author(s) 2020

\section{Correction to: Journal of Natural Medicines https://doi.org/10.1007/s11418-020-01393-x}

The article Enzymatic studies on aromatic prenyltransferases, written by Takahiro Mori, was originally published electronically on the publisher's internet portal on 17 March 2020 without open access. With the author(s)' decision to opt for Open Choice the copyright of the article changed on 22 May 2020 to (c) The Author(s) 2020 and the article is forthwith distributed under a Creative Commons Attribution 4.0 International License (https://creativecommons.org/licen ses/by/4.0/), which permits use, sharing, adaptation, distribution and reproduction in any medium or format, as long as you give appropriate credit to the original author(s) and the source, provide a link to the Creative Commons licence, and indicate if changes were made.

The original article can be found online at https://doi.org/10.1007/ s11418-020-01393-x.

\section{Takahiro Mori}

tmori@mol.f.u-tokyo.ac.jp

1 Graduate School of Pharmaceutical Sciences, The University of Tokyo, 7-3-1 Hongo, Bunkyo-ku, Tokyo 113-0033, Japan
The original article was updated.

Open Access This article is licensed under a Creative Commons Attribution 4.0 International License, which permits use, sharing, adaptation, distribution and reproduction in any medium or format, as long as you give appropriate credit to the original author(s) and the source, provide a link to the Creative Commons licence, and indicate if changes were made. The images or other third party material in this article are included in the article's Creative Commons licence, unless indicated otherwise in a credit line to the material. If material is not included in the article's Creative Commons licence and your intended use is not permitted by statutory regulation or exceeds the permitted use, you will need to obtain permission directly from the copyright holder. To view a copy of this licence, visit http://creativecommons.org/licenses/by/4.0/.

Publisher's Note Springer Nature remains neutral with regard to jurisdictional claims in published maps and institutional affiliations. 